\title{
Cooperating Teachers' Knowledge, Belief and Commitment to Their Mentoring Role of PGDT (Post Graduate Diploma in Teaching) Trainees: The Case of Cooperating Teachers in Bahir Dar City, Ethiopia
}

\author{
Alemayehu Habte Melkamu \\ Lecturer, Dilla College of Teacher Education \\ Ph.D Student at Bahir Dar University, College of Education and Behavioral Sciences, Department of \\ Curriculum studies and Teacher Education \\ Bahir Dar, Ethiopia
}

\begin{abstract}
The purpose of this study was to investigate cooperating teachers' knowledge, beliefs and commitment of mentoring PGDT trainees of Bahir Dar University. Adopting descriptive survey design, the study took 43 cooperating teachers using stratified random sampling procedure. The findings indicated that cooperating teachers had adequate knowledge of the goals and processes of mentoring but have limited belief in the impact of mentoring on the professional disposition of student-teachers. Furthermore, the result revealed that cooperating teachers did not view mentoring as an opportunity for professional development. Consequently, the situation requires that cooperating teachers need tailored training on mentoring and the need for consolidating the collaboration between university tutors and cooperating teachers was suggested as possible recommendations. Keywords: PGDT, Mentoring, Cooperating Teachers.
\end{abstract}

DOI: $10.7176 / \mathrm{JCSD} / 47-04$

Publication date: April $30^{\text {th }} 2019$

\section{Introduction}

Teaching is a very complex profession and formative in nature, one grows within the profession through daily experiences. Becoming a teacher is transformational in nature. It is about developing one's own personal and professional identity. Such an identity can be obtained and enriched only by taking part in well-articulated practicum experience.

The quality of student-teachers practicum experience in turn largely depends on the quality of mentoring. Mentoring is often a collaborative effort between university supervisors, teacher educators, school administrators, supervising teachers, and pre-service teachers (Schwille, 2008). Particularly, the mentoring relationship between student-teachers and cooperating teachers is one of the most significant components of the student teaching experience (Practicum).

Mentoring has been conceptualized differently by different scholars. Malderez (2001) defined it as the support given by experienced person for the growth and learning of another, and for their integration into and acceptance by a specific community. Others defined it as a particular mode of learning wherein the mentor not only supports the mentees, but also challenges them productively so that progress is made' (Smith 2007). Another definition, yet a more comprehensive one, conceptualizes mentoring as a nurturing process in which a more skilled or more experienced person serves as a role model, teaches, sponsors, encourages, counsels and befriends a less skilled or less experienced person for the purpose of promoting the latter's professional and or personal development (Anderson, 1987). The definitions suggest that mentoring is a key element in fostering pre-service teachers' personal and professional development (Schmidt, 2008). Moreover, the mentoring process requires a flexible role to be adopted by cooperating teachers.

Mentoring is not only about the support student-teachers obtain during their practicum experience but also the challenges cooperating teachers pose to their mentees so that progress is made (Smith 2007). This indicates that student teachers misconceptions need to be challenged so as to develop professionally competent, confident future professionals. To this end, an environment in which student-teachers try out alternative instructional strategies and innovative approaches needs to be enhanced. Mentoring involves guidance and suggestion, as well as the development of autonomous skills, judgments, personal and professional mastership, expertise, trust and the development of self-confidence over time (O'Brien \& Hamburg, 2014).

Today, mentoring is seen as 'complex social interactions that cooperating teachers and student teachers' construct and negotiate for a variety of professional purposes and in response to the contextual factors they encounter (Fairbanks, Freedman \&Kahn, 2000). Accordingly, mentors (cooperating teachers) can play various roles depending on the circumstances and the particular needs of the mentee. In this regard, cooperating teachers can take the roles of modeling (to inspire and demonstrate), acculturating (to help mentee to get acculturated into the professional culture), sponsoring (to use their power in the service of the mentee), and educating (to achieve 
professional learning objectives) (Fullerton \& Malderez, 1998).

The success of the mentoring process largely depends on the competence and professional commitment of the cooperating teacher. Harrison, Dymoke, and Pell (2006) assert that cooperating teachers have a responsibility to make changes in the professional beliefs, values and behaviors of their mentees. They should provide sustained guidance and support in a collaborative nature (Schneider, 2008). For this, cooperating teachers should have the required subject matter as well as pedagogical expertise. Other scholars such as Schmidt (2008) also emphasize the importance of mentor-mentee relationship. The cooperating teacher also needs to be a good listener, flexible, and able to initiate discussion and reflection on practice (Hudson, et al., 2009). To this end, cooperating teachers should demonstrate the desired teaching behaviors expected of student teachers after completion of the initial teacher training.

Moreover, cooperating teachers are expected to have high motivation and commitment to the profession in general and to their mentoring role in particular. Overall, the quality of practicum during initial teacher training largely depends on the degree to which cooperating teachers are committed enough and exhibit positive attitudes which in turn has tremendous impact on the perceptions of student teachers about the teaching profession.

In fact, mentoring should be viewed as a symbiotic relationship which benefits both student teachers and cooperating teachers (Heirdsfield, Walker, Walsh \& Wilss, 2008). Cooperating teachers and mentees must collaboratively develop teaching knowledge while cooperating in a school context (Nilsson \& van Driel, 2010). For this to happen, a perspective that considers mentoring as complex social interactions that cooperating teachers and student teachers construct and negotiate for various professional purposes and in response to contextual factors (Fairbanks, Freedman \& Kahn, 2000) needs to be adopted in teacher education programs.

In Ethiopian context, the place of practicum in general and mentoring in particular has witnessed a swinging shift of emphasis in the history of secondary teacher education. Until recently, the practicum received inadequate emphasis and was inefficiently implemented at all levels of teacher education (MoE, 2003). Also, participation of cooperating teachers in secondary teacher education programs received little acknowledgement.

This and other deficiencies led to a reform known as Teacher Education System Overhaul (TESO). The TESO aimed at producing competent secondary school teachers through prolonged practicum periods that accounted for 25 credit hours of the total 108 credit hours the prospective secondary school teacher was supposed to take. Nevertheless, the large number of trainees and the demand for large financial resources and transportation scheme has crippled the plan from the start. As a result, university supervisors (tutors) were compelled to focus on grading than advising. The role of cooperating teachers was not different. They lacked adequate time for providing adequate feedback for each student-teacher. Overall, practicum during the TESO largely followed a "Sink or Swim" approach where student-teachers faced the challenging realities of classrooms without adequate support. Soon enough the TESO was confirmed as failure resulting in teacher graduates who felt incompetent mostly both ways, sometimes in either.

Adopting a consecutive approach, the current secondary teacher education program, the Post Graduate Diploma in Teaching (PGDT) aimed at overcoming the limitation of its predecessor. In this regard, it targeted to give due emphasis to the subject matter knowledge, pedagogical skills and affective elements of the teaching profession. Likewise, graduates of applied degrees $(\mathrm{BA} / \mathrm{BSc})$ were made to join the profession willingly. The structure was made to be consecutive so as to arm graduates both ways, in subject matter and pedagogical skills. The practicum component was made to receive relatively less emphasis but with a shift in philosophy. Instead of adhering to the apprenticeship model of mentoring, the PGDT promotes the collaborative inquiry model to mentoring, where the mentees were considered as change agents to impact change in secondary schools. Hence, they were thought as a colleague to cooperating teachers who work collaboratively engaged in reflection rather than emulators. In this modality of teacher training, student-teachers go out for practicing teaching in the nearby schools for a period of one month where they were supposed to practice teaching with the help of cooperating teachers and university supervisors.

\subsection{Statement of the Problem}

The success of mentoring to a large extent depends on the knowledge, skills and commitment of cooperating teachers. While cooperating teachers must have deep insight into teaching and teaching practices, mentoring requires a set of skills that includes being able to clearly articulate their practices and helping and supporting student-teachers so as to facilitate their learning (Rhodes, Stokes \& Hampton, 2004). As such, mentoring relationships are most effective when cooperating teachers are trained for their roles (Pitton, 2006; Wong, 2005).

Nevertheless, while training on mentoring skills is the single most important factor in contributing to mentoring success (Sweeny, 2008), few teachers receive formal training to prepare them adequately for mentoring roles. Being a mentor requires skill, knowledge \& commitment. Furthermore, good mentor-mentee relationship enhances the growth and professional development of the mentor or more experienced teacher as well (Hastings, 2004).

There were some studies conducted to examine cooperating teachers' perceptions of their own role as 
cooperating teachers of student teachers (Doty, 2006; Zemek, 2008). In Ethiopian context, some studies were conducted on issues related to secondary school teachers' training program known as the PGDT. Some of these studies focused on attitude of student teachers towards the teaching profession (Koye, 2014; Adugna, 2012), challenges and practices of the training with a focus on the selection and admission processes of candidates (Koye \& Yonas, 2013). Others focused on the practices and challenges of postgraduate diploma in teaching practicum implementation (Mohammed et al., 2014).

In case of Bahir Dar University, there were certain studies conducted on issues related to mentoring. For instance, a study by Kindie (2015) investigated the perception of summer modality prospective teachers of Bahir Dar University toward the role execution of student teachers, cooperating teachers and university instructors in prospective teachers' practicum. The author concluded that the role played by cooperating teachers during practicum was inadequate. In another study, Demis et al. (2015) explored the views and perceptions of English Major Prospective Teachers towards Post Graduate Diploma in Teaching (PGDT) training in general and the teaching profession in particular taking a sample of prospective teachers enrolled in Bahir Dar and Haramaya University.

Another study by Solomon (2013) was conducted on an issue relatively related to the present study. The study examined the state of student-teachers' support service rendered by cooperating teachers. The study was carried out on education faculty student-teachers from 2007-2008 of Bahir Dar University. The study was conducted on student-teachers of the TESO program, not to mention it measured mentoring support of cooperating teachers from student-teachers perspectives.

The above studies focused on either the practices or challenges of PGDT in general or other related issues such as student-teachers perception of their own skills, knowledge, and preparation and their perception of cooperating teachers in particular. Though the studies raised the issue of mentoring in one way or another, most of them either treated it as a subordinate issue, or tried to understand mentoring role of cooperating teachers from the perspective of student-teachers. In fact, none of them tried to see how cooperating teachers viewed their role in relation to their own professional development. Hence, studies which typically assess cooperating teachers' perceptions of their role as a mentor and their commitment to it are rare.

Thus, studying the perceptions of cooperating teachers is crucial because they provide an outside perspective on the assessment of teacher education programs. Because cooperating teachers offer such a unique perspective, and because mentoring of PGDT trainees has not been duly examined, a gap exists in the research on cooperating teachers' perspective on their view of the mentoring role, their commitment to it and the challenges they faced. Hence, the purpose of this study was to investigate cooperating teachers' knowledge, belief and commitment to mentoring role with particular reference to cooperating teachers in secondary schools of Bahir Dar City.

\subsubsection{Research Questions}

- To what extent do cooperating teachers understand the goal and processes of mentoring?

- To what extent do cooperating teachers believe in the role of mentoring towards mentees' professional disposition?

- What is the extent of cooperating teachers' commitment to the mentoring role?

- Is there statistically significant relationship among cooperating teachers' knowledge, belief and commitment to mentoring role?

- What are the challenges of mentoring role, as perceived by cooperating teachers?

\section{Review of Related Literature}

\subsection{The Concept of Mentoring}

The concept of mentoring implies some form of psychological bonding between the mentor and the mentee. The mentor develops a genuine interest in the mentee and feels rewarded with each success that the mentee acquires, which implies an emotional investment on the part of the mentor. The mentor not only supplies information and gives advice but also offers critical support for the mentee at times of need.

Mentoring is a process by which one person assists another to grow and learn in a safe and sympathetic environment. Mentoring enables an individual to follow in the path of an older and wiser colleague who can pass on knowledge, experience and open doors to otherwise out of reach opportunities.

Cooperating teachers try to help student teachers to reflect up on their experiences, to develop an understanding, and to apply these understanding to new situations. The process involves looking to values and feelings as well as developing skills and building theories about why things happen as they do (Colley, 2003).

Different authorities define mentoring based on their profession and experience. A mentor had been conceptualized as experienced counselor, guide, teacher, advisor and supporter; somebody, usually older and more experienced, who advices and guides a younger, less experienced person. And mentoring was coined as the task of acting as a mentor to somebody especially to a junior colleague.

Jan Cummings (1999) as cited in (Stockdale, 2002) defined mentoring as a relationship and developmental 
partnership through which, the mentee, with the assistance from the mentor sets goal for the key purpose of development of the mentee. Enhancing skills, gaining knowledge and implementing new behaviors are the intended targets of mentoring program. For Sweeny (2008), mentoring is a nurturing process in which a more experienced person, serving as a role model, teacher and sponsor encourages, counsels and befriends a less skilled or less experienced person for the purpose of promoting the latter's professional and/or personal development.

Mentoring functions are carried out within the context of an ongoing, caring relationship between the mentor and the mentee. It is more than a role with a list of preconceived duties, rather it is a unique personal relationship, characterized by trust, sharing of expertise and moral support, knowing when to provide access to this expertise and support, and when it should be withheld (Awaya et.al, 2003). Essential elements in definitions of mentoring are that it is multidimensional and multifunctional developmental relationship that evolves over time. These elements distinguish mentoring from its individual components, establishing mentoring relationships as an example of the sum being greater than its parts.

\subsection{Benefits and Purposes of Mentoring}

Teacher education institutions and schools must find ways to be planned about what values and cultural norms are passed to prospective teachers. This demands well-articulated theoretical training and practicum experience that arms prospective teachers with a reflective attitude which helps them build on the best experiences and collaboratively work with cooperating teachers for the improvement of teaching practices in the respective secondary schools they go out for practicum.

Benefits of mentoring extend to mentees, cooperating teachers and the schools as organizations. Mentees benefit because someone cares enough to support them and advise them. For cooperating teachers, the benefits are of more personal and professional in nature. Mentoring provides the mentor with the opportunity to reflect on his or her own skills and practices. Working with a novice also exposes the mentor to new ideas. Cooperating teachers experience the fulfillment of passing along hard-earned wisdom, influencing the next generation of teachers and receiving appreciation from new teachers which in turn enhance a sense of accomplishment.

The relationship also provides cooperating teachers a place to learn about generational and cross-cultural differences. Finally, there is personal satisfaction in teaching and sharing one's experiences. The school benefits when the optimism and the energy of younger, more culturally, technologically diverse student-teacher interests with the efficiency and confident decision-making skills of more experienced teachers. Ideally, mentoring of new teachers reduces turnover, helps them deal with organizational issues and accelerates their assimilation into the culture (Kram, 1985).

Mentoring also creates cohesive schools that promote teacher professional training through learning communities. Mentoring retains quality teachers who understand the school culture. Increased organizational commitment and decreased turnover are the organizational benefits of mentoring (Raabe, 2003). For student teachers, mentoring expands their knowledge of the theories and practices of the teaching profession. They gain the opportunity to discuss educational issues with an experienced person, which in turn results in improved teaching performance and promotes student learning and engages in professional growth activities that enhance knowledge of effective strategies and techniques.

Cooperating teachers provide mentees guidance to easily get along with the school community. Furthermore, mentees receive honest, constructive feedback, as well as ongoing support and encouragement (Boyle \& Boice, 1998). Mentoring has proven to be a useful tool in retention of employees (Holloway, 2011). Effective mentoring experience leads to beginning teacher's satisfaction and competence in teaching; consequently, professional growth of mentored teachers outpaces non-mentored ones. This in turn, increases the retention level of new teachers.

Referring to the purpose of mentoring, Kreitner and Kinicki (2004) observed that it is essential to promote high performance culture, because it creates a sense of oneness by enhancing commonly held organization values. Its socialization aspect helps to build belongingness among members and increase the interaction among staff. The overall objective of mentoring is to give newcomers a local guide, but the character and content of these programs also vary widely. Duration and intensity, for example, may be very different from program to program.

\subsection{Models of Mentoring}

There are different models that have been adopted by teacher education institutions as a means of producing qualified teachers. These include the knowledge transmission model, the theory and practice connection model, the collaborative inquiry model, the apprenticeship model and the competence based model.

\subsubsection{The Knowledge Transmission Model}

The knowledge transmission model assumes that knowledge of mentoring comes from research rather than from mentors' own experiences and practices, so that such knowledge can be transmitted to mentors in the form of 
discrete concepts and skills. Although this model helps mentors to develop many mentoring skills and techniques, there is no evidence that mentors are able to apply such learning in their practice with interns (Evertson \& Smithey, 2000).

\subsubsection{The Theory-And-Practice Connection Model}

The theory-and-practice connection model assumes that knowledge of mentoring comes both from research and mentors' practical knowledge, so that mentoring skills and knowledge should be actively constructed by mentors and then through integration of their practical knowledge of teaching and learning, with the support of teacher educators. This model, unlike the transmission model influences mentors' sensitivity to the needs and problems of mentees. In this model, teacher educators are still distant from actual mentoring practice (Wang \& Odell, 2002).

\subsubsection{The Collaborative Inquiry Model}

The collaborative inquiry model stresses mentors' active construction of mentoring knowledge through the integration of their practical knowledge of teaching, the application of what they have learned in practice and constant dialogue with teacher educators. The distinction of this model from the theory-and-practice connection model in that teacher educators work with mentors and mentees residing in the context of teaching and mentored learning to teach. Through this process, the teacher educator helped to deepen the mentor's understanding of practice. This model not only values mentors as learners who actively inquiry into teaching and mentoring but also views teacher educators as learners who examine and develop the knowledge and skills of mentoring in the context of teaching and mentoring. In this model, mentors, mentees, and teacher educators are all researchers, learners, contributors of knowledge related to teaching and mentoring.

\subsubsection{The Apprenticeship Model}

In the apprenticeship model learning is done through emulation of an experienced practitioner. From this perspective, to be a mentor is simply to act as a model offering practical tips, not requiring any particular skills.

The apprenticeship model is viewed as the traditional model of mentoring. Apprenticeship model is derived from how people were trained in different industrial trades. Apprenticeship model is characterized by participation in a community of practice; professional identity; learning through imitation of the mentor; and the quality of the work is evaluated through practice.

The apprenticeship model emphasizes learning by doing and observing and emulating others doing it. It entails learning from experienced teachers. The student teacher is attached to an experienced teacher and at the same time is responsible for teaching some of the subjects in the curriculum. In this regard, the student teacher under the apprenticeship model is like an apprentice in some form of industry where he/she learns the skills of the teaching in a real classroom situation, with real students and applying proper classroom approaches. The student teacher is able to gain knowledge from those who are more experienced through participating in ongoing daily routines and activities, which encourages relationships critical to developing norms and values of the profession.

The apprenticeship model of mentoring is therefore characterized by how human beings learn through modeling. It appears to support social learning theories by psychologists like Albert Bandura. Bandura advanced the social learning theory in which he advocated for learning through modeling. Such modeling involves observing others. Like with the apprenticeship model of mentoring, Bandura's social learning theory has the following factors that are key to the success of learning through modeling: the ability of the learner to pay attention; the ability to remember and retain what has been observed or learned; the ability to reproduce what has been learnt from the model; and lastly, there should be the motivation to imitate the model. To this end, the relationship between the mentor (Cooperating teacher) and student teacher (mentee) becomes critical.

The apprenticeship model has its own limitations as a model of providing teacher education. Such problems are related to the selection of the mentors. If the mentors do not have the requisite skills that they should share with the mentee, this is most likely to have a negative impact on the professional disposition of the mentee. In that regard a mentor should be competent in contemporary learning theories and committed to the profession. If student teachers are exposed to teachers of a poor quality in their apprenticeship chances of them becoming bad teachers are high (Stones, 1988 cited in Samkange, 2015). This calls for continuous training of cooperating teachers and careful selection process.

\subsubsection{The Competence Model}

This model advocates a more systematic skill-based approach to learning to teach. The mentor is a trainer in the sense that pre-determined performance standards guide their mentoring. The student teacher and the mentor have to focus on the development of competencies that will assist the student to become a competent teacher. The focus is on helping the student teachers to acquire professional qualifications in teaching practice. Within the context of these competencies there are at least four aspects that we are concerned with in the development of the student teacher. These are the professional knowledge base of the student teacher, teaching skills, lesson evaluation and assessment of pupils' work (Maynard and Furlong, 1992).

The role of the mentor within the context of the competence model is that the mentor becomes the coach 
and the student teachers are given responsibilities over their class. Such an arrangement enables the student teachers to teach as they learn and learn as they teach. This promotes the student teachers chances of trying their own ideas. If the student teachers are to develop the required competencies, it is important that they have full control and responsibilities of their classes with the mentor coming in as a coach. Through this model student teachers are expected to apply the knowledge, skills, abilities, behaviors, and perform critical teaching tasks (Ennis, 2008 cited in Samkange, 2015).

\section{Methodology}

\subsection{Research Approach and Design}

The study adopted a quantitative approach to study the issue under investigation. The design of this study was descriptive survey. The design was chosen because it is suitable to gather data on relatively many issues within a manageable period of time. Furthermore, it enables to obtain cooperating teachers' perception of mentoring role and their commitment to their role in a very short time provided. As supported by Kothari (2004), descriptive research is relevant in describing, recording, analyzing and interpreting current conditions of a particular individual or group.

\subsection{Target Population}

The target population of the study was all secondary school teachers (Cooperating teachers) of Bahir Dar City who served as cooperating teachers for PGDT trainees in the year 2017. In the four secondary schools of Bahir Dar city, they were about 153 secondary school teachers who served as cooperating teachers.

\subsection{Sample Size and Sampling Procedure}

There were four secondary schools in Bahir Dar city to which PGDT trainees of Bahir Dar University were assigned for their one month practicum experience as part of the one year training to be certified as a secondary school teachers. From the five schools (Failo secondary school, Tana Haik secondary school, Ghion secondary School, Dilchibo secondary school and Bahir Dar Mesenado preparatory schools) two schools (Fasilo secondary school and Gihon secondary school) were randomly chosen and all teachers of the two schools who served as cooperating teachers were taken as participants of the study by default. Accordingly, there were 62 cooperating teachers who served as cooperating teachers (10 in Fasilo secondary school and 52 in Ghion respectively). All of them (62 cooperating teachers) were taken as a sample.

\subsection{Data Collection Tools}

In this study, quantitative data were collected using self-administered questionnaire distributed by the researcher himself with short briefing about the purpose of the study. The questionnaire was prepared by the researcher through consulting relevant literature and prior empirical studies. Since the respondents were secondary school teachers who were holders of BA/BSc and above, the questionnaire was prepared and administered in English language.

The questionnaire consisted of six parts. The first part included items which address demographic and other background information, while the remaining parts included items focusing on knowledge of goals and processes of mentoring, belief about the impact of mentoring on student-teachers professional disposition, perception of mentoring as professional development, commitment to mentoring and challenges of mentoring role. Except the first and the last part of the questionnaire (i.e. Background information and challenges of mentoring role) all the other parts were measured using a five point Likert scale where $1=$ strongly disagree, 2=disagree, 3= uncertain/not sure, $4=$ agree and $5=$ strongly agree. Likert scale was chosen for their proven suitability to measure belief and perception. Negatively worded items were reverse scored. The last part of the questionnaire (challenges of mentoring role) was measured in a four point likert scale where 1, 2,3 \& 4 represented 'Not a challenge at all', 'A challenge with a minor impact', 'A moderate challenge' and 'A very serious challenge' respectively.

\subsubsection{Validity of the Instrument}

Two types of Validity were checked in this study: Face and Content Validity. Face validity refers to whether the items of the questionnaire truly measure what they were supposed to measure. To ascertain face validity of the items, the questionnaire was given to fellow Ph.D candidates and substantial comment was received and some improvements were made on certain items. Moreover, relevant literatures were consulted. The same procedure was done to ensure the extent to which the items reflect the theoretical content domain of the construct being measured (Content validity).

\subsubsection{Reliability of the Instrument}

Cronbach's alpha coefficients were computed for each measurement scale to check the reliability or internal consistency of items. The result indicated that the alpha coefficients for each scale were above $\alpha=.70$. Thus, there was adequate level of internal consistency among the items in all scales. Pilot testing revealed the 
reliability results were: Knowledge of goals and processes of mentoring $(\alpha=.78)$, belief about the impact of mentoring on student-teachers professional disposition $(\alpha=.87)$, perception of mentoring as professional development $(\alpha=.82)$, commitment to mentoring $(\alpha=.86)$ and challenges of mentoring role $(\alpha=.71)$.

\subsection{Data Analysis Techniques}

Data were analyzed using both descriptive statistics (Percentage, mean \& SD) and inferential statistics such as one sample t-test and Pearson coefficient of correlation analysis. One sample t-test was used to examine the level of knowledge and belief of cooperating teachers regarding their mentoring role and the extent of their commitment to it. Pearson correlation was computed to see if there is statistically significant relationship among Cooperating teachers' commitment to their knowledge of mentoring, and mentoring belief. The quantitative data was coded and analyzed using SPSS version 20.

\section{Results and Discussion}

\subsection{Results}

The purpose of this study was to investigate cooperating teachers' knowledge, belief and commitment to mentoring role with particular reference to cooperating teachers in secondary schools of Bahir Dar City. This section of the paper presents the results and interpretations of the data obtained through questionnaire.

Table1: Background Characteristics of Respondents

\begin{tabular}{lll}
\hline Category & $\boldsymbol{N}$ & $\%$ \\
\hline Gender & & \\
$\quad$ Female & 8 & 18.6 \\
Male & 35 & 81.4 \\
Education Status & & \\
BA/BSc & 37 & 86.0 \\
MA/MSc & 6 & 14.0 \\
Mentoring Experience & & \\
only 1 year & 7 & 16.3 \\
2 to 3 years & 19 & 44.2 \\
4 to 7 years & 6 & 14.0 \\
8 to 12 years & 2 & 4.7 \\
13 years \& above & 9 & 20.9 \\
Teaching Experience & & \\
8 to 11 years & 4 & 9.3 \\
12 to 16 years & 5 & 11.6 \\
17 years \& above & 34 & 79.1 \\
\hline
\end{tabular}

Table 1 above presents the demographic characteristics and background information of sampled respondents. As it can be seen in the table, the majority $(81.4 \%)$ of the respondents were male while the remaining $18.6 \%$ were female. This might suggest that the number of female cooperating teachers was inadequate. This particularly requires attention since there are gender related challenges faced by female studentteachers.

Regarding education status, $86 \%$ of them reported that they had BA/BSc degrees, while $14 \%$ indicated they hold MA/MSc degrees. Due to the nature of the objective of the study which aimed at discovering the perception and commitment of cooperating teachers, data was collected with those who had served as a mentor at least once. Accordingly, the majority of the sampled respondents $(44.2 \%)$ reported a mentoring experience between 2-3 years, followed by those who reported a mentoring experience of above 12 years. This group accounted for $20.9 \%$ of the respondents. About $16.3 \%$ respondents reported they had only 1 year experience.

The majority $(79.1 \%)$ of the respondents reported they had above 17 years of teaching experience. The remaining $9.3 \%$ and $11.6 \%$ of the respondents reported a teaching experience ranging between 8 to 11 years and 12 to 16 years respectively. The result indicated that most cooperating teachers were seasoned and well experienced in the teaching profession. 
Table 2: Background work related information of respondents

\begin{tabular}{|c|c|c|}
\hline Items & $N$ & $\%$ \\
\hline \multicolumn{3}{|l|}{ Teaching Workload/Week } \\
\hline 11 to 15 periods & 18 & 41.9 \\
\hline 16 to 20 periods & 19 & 44.2 \\
\hline 21 periods \& above & 6 & 14.0 \\
\hline \multicolumn{3}{|l|}{ Frequency of training } \\
\hline None & 20 & 46.5 \\
\hline Once & 19 & 44.2 \\
\hline Twice & 2 & 4.7 \\
\hline three times \& more & 2 & 4.7 \\
\hline \multicolumn{3}{|c|}{ On average, how often do you discuss with your mentee in a week? } \\
\hline Once & 21 & 48.8 \\
\hline Twice & 10 & 23.3 \\
\hline three times & 4 & 9.3 \\
\hline Everyday & 8 & 18.6 \\
\hline \multicolumn{3}{|c|}{$\begin{array}{l}\text { In a single pre-classroom observation session, how much time do you take } \\
\text { to discuss issues with the mentee (on average)? }\end{array}$} \\
\hline no discussion at all & 8 & 18.6 \\
\hline$<15$ minutes & 15 & 34.9 \\
\hline 15 to 30 minutes & 20 & 46.5 \\
\hline \multicolumn{3}{|c|}{$\begin{array}{l}\text { In a single post-observation session, how much time do you take to discuss } \\
\text { issues with the mentee (on average)? }\end{array}$} \\
\hline No discussion at all & 1 & 2.3 \\
\hline$<15$ minutes & 22 & 51.2 \\
\hline 15 to 30 minutes & 17 & 39.5 \\
\hline 30 to 60 minutes & 3 & 7.0 \\
\hline
\end{tabular}

As indicated in table 2 above, about $44.2 \%$ of the respondents reported that they teach 16-20 hours per week. The percentage of cooperating teachers who reported a weekly teaching load between 11 to 15 hours is $41.9 \%$. Only $14 \%$ of then reported a teaching load above 21 hours per week.

Mentorship training is an important element for successful teaching practice. In this regard, respondents were asked about whether they took training particularly focusing on mentoring. It is found that the majority $(46.5 \%)$ never attended any training at all, while $44.2 \%$ reported they had participated on training at least once. About $4.7 \%$ reported they had attended training twice. The number of cooperating teachers who took training more than three times was $4.7 \%$.

Collaborative relationship and open discussion determines the success of mentoring. In this regard, respondents were asked about the frequency of meetings they hold with mentees. Accordingly, about $48.8 \%$ of them reported they held conferences only once, while the respondents who held conference twice and three times account for $23.3 \%$ and $9.3 \%$ of the respondents respectively. About $18.6 \%$ reported they had held conferences almost every day.

Pre and post observation sessions help cooperating teachers and mentees discuss on the strengths and areas of improvement. Likewise the two parties need to spend adequate time together planning and reflecting on the teaching practices of the mentee. In this regard, $46.5 \%$ of the respondents reported that they spent 15 to 30 minutes during the pre-classroom observation sessions while $34.9 \%$ reported they spent less than 15 minutes in pre-observation conferences. About 18.6\% reported they had never had pre-observation sessions.

Post-observation session aims at helping the mentee reflect on the strong sides and areas of improvement that needs his/her immediate attention. Likewise, cooperating teachers are expected to hold a post-observation conference with their mentees. In this regard, about 7\% of them reported they had meetings for about 30 to 60 minutes. Slightly more than half $(51.2 \%)$ of them held meetings for about 15 minutes. The remaining $39.5 \%$ reported they held post-observation sessions for about 15 to 30 minutes. Only $2.3 \%$ reported they did not have any communication with mentees after classroom observation. 
Table 3: Knowledge of Cooperating teachers regarding the goal and processes of mentoring

\begin{tabular}{lll}
\hline \multicolumn{1}{c}{ Items } & Mean & SD \\
\hline I know exactly what my responsibilities as a mentor are. & 3.79 & 0.97 \\
I know exactly what is expected of me as a mentor. & 3.51 & 0.94 \\
I have adequate knowledge on what and how to guide mentees during practicum & 3.19 & 0.88 \\
I have clear understanding about the goals and activities of practicum & 3.14 & 1.3 \\
I am well informed and aware about the purpose of practicum program & 3.33 & 0.92 \\
I know how to approach \& manage smooth relationship with mentees. & 3.56 & 1.24 \\
Grand Mean & $\mathbf{3 . 4 2}$ & $\mathbf{0 . 8 9}$ \\
\hline
\end{tabular}

As clearly put in the table above, the mean scores for the six items which were intended to measure knowledge of cooperating teachers regarding the goals and process of mentoring was above the expected mean value. The mean score for knowledge of responsibilities was $M=3.79, S D=0.97$. The mean score for the overall scale was $M=3.42, S D=0.89$. The result indicated that cooperating teachers had above average knowledge of their roles as a mentor and the goals of mentoring including the meanses for approaching mentees.

Table 4: Belief of Cooperating Teachers Regarding the impact of mentoring on student-teachers' professional disposition

\begin{tabular}{lcc}
\hline \multicolumn{1}{c}{ Items } & Mean & SD \\
\hline $\begin{array}{l}\text { If mentees have no prior motivation to be a teacher, they are not likely to accept any } \\
\text { advice \& support I offer them during practicum. }\end{array}$ & 2.67 & 1.17 \\
$\begin{array}{l}\text { A mentor is very limited in shaping the skill \& knowledge of mentees because mentees' } \\
\text { social background is a large influence on his interest to be a teacher. }\end{array}$ & 2.67 & .97 \\
$\begin{array}{l}\text { The amount of time a mentee spends with me will have little influence on his/her attitude } \\
\text { to teaching profession compared to the influence of his/her home (social) environment. }\end{array}$ & 2.72 & .59 \\
$\begin{array}{l}\text { Even a committed mentor with good teaching abilities and mentoring skills cannot } \\
\text { change mentees' negative attitude to the teaching profession. }\end{array}$ & 2.77 & .84 \\
$\begin{array}{l}\text { The negative influences of mentee's background and social environment on his/her } \\
\text { attitude to the teaching profession can be overcome by good mentoring. }\end{array}$ & 2.98 & .96 \\
$\begin{array}{l}\text { I am certain that I will manage to ensure even the most unmotivated mentee obtain good } \\
\text { mentoring support during practicum in our school. }\end{array}$ & 2.95 & .49 \\
Grand Mean & $\mathbf{2 . 7 9}$ & $\mathbf{. 5 7}$ \\
\hline
\end{tabular}

The fourth part of the questionnaire was intended to measure cooperating teachers' beliefs about their perceived influence on student-teachers professional disposition and motivation for the profession. Cooperating teachers beliefs in their ability to motivate their mentees to love the profession was below average $(\mathrm{M}=2.67$, $\mathrm{SD}=1.17$ ). They also believed that their influence on the mentee as compared to social background influences was minimal $(\mathrm{M}=2.67, \mathrm{SD}=0.97)$. They also believed that the home environment of the mentee had the most influence than the amount of time the mentee spends with cooperating teachers $(\mathrm{M}=2.72, \mathrm{SD}=0.59)$. Overall, cooperating teachers believed that the influence of mentoring on student-teachers' professional disposition and attitude to the profession was below the expected mean value $(M=2.79, S D=0.57)$.

Table 5: Commitment of Cooperating Teachers to mentoring role

\begin{tabular}{lcc}
\multicolumn{1}{c}{ Items } & Mean & SD \\
\hline I feel that I have adequate time to work with my mentee. & 3.12 & 0.96 \\
The mentoring role is professionally satisfying role for me. & 3.35 & 1.13 \\
I allow mentees to join my class for observation even if it is outside the practicum period. & 3.77 & 0.92 \\
It is difficult to guide mentees without financial remuneration. & 2.74 & 1.26 \\
As a mentor I am dedicated to help mentees even outside their regular time. & 3.51 & 1.03 \\
I am pleased to be able to sign up as a mentor. & 3.49 & 1.12 \\
It doesn't worry me to be observed by student teachers while teaching. & 3.28 & 1.39 \\
With or without prior training I like mentoring student teachers. & 2.91 & 1.32 \\
Grand Mean & $\mathbf{3 . 2 7}$ & $\mathbf{0 . 8 3}$ \\
\hline
\end{tabular}

Student-teachers model not only pedagogical practices of their cooperating teachers but their enthusiasm and love for the teaching profession. As such schools need to assign cooperating teachers not only based on their teaching expertise and subject matter know how but also on their love to the profession. This is because teachers 
who love their profession will be more committed to their role of mentoring student-teachers. Due to this, the fifth part of the questionnaire was intended to measure the commitment of cooperating teachers to their mentoring role.

For most of the items in this scale, the mean score of the respondents was found to be above the expected mean value. But respondents' mean score for the two of the items i.e. "it is difficult to guide mentees without financial remuneration" and "with or without prior training, I like mentoring student-teachers" was found to be below the expected mean value. The mean score for the two items was $M=2.74, S D=1.26$ and $M=2.91, S D=1.32$ respectively. Nevertheless, the grand mean score for the overall scale was $M=3.27, S D=0.83$, which was above the expected mean value.

Table 6: Perception of Cooperating teachers regarding mentoring as an opportunity for Professional development

\begin{tabular}{lll}
\hline \multicolumn{1}{c}{ Items } & Mean & SD \\
\hline Renews my enthusiasm to the teaching profession. & 2.93 & 1.37 \\
Enhances my skills in coaching, counseling, listening, and modeling. & 3.44 & 1.18 \\
Gives me an opportunity to demonstrate my expertise and share knowledge. & 3.47 & 1.24 \\
Helps me to improve my own teaching practices. & 2.74 & 1.22 \\
Helps me to become more self-critical and reflective in my own practices. & 2.81 & 1.35 \\
Helps me improve skills in monitoring and evaluating classroom practice. & 3.47 & 1.14 \\
Offers me the opportunity to develop leadership skills. & 2.56 & 1.32 \\
Grand Mean & $\mathbf{3 . 0 6}$ & $\mathbf{1 . 1 7}$ \\
\hline
\end{tabular}

The sixth part of the questionnaire was aimed at whether the cooperating teachers viewed mentoring as an opportunity for professional development. The overall mean score for this scale was $M=3.06, S D=1.17$, which was slightly above the expected mean value. The item wise analysis revealed that cooperating teachers did not view mentoring as an opportunity for developing leadership skills $(M=2.56, S D=1.32)$, they also did not see it as an opportunity for improving their own teaching practices $(M=2.74, S D=1.22)$, contributing little to become selfcritical and reflective in their own practice $(M=2.81, S D=1.35)$ and with little impact on renewing their enthusiasm for the profession $(M=2.93, S D=1.37)$. The result further indicated that cooperating teachers viewed mentoring as an opportunity to demonstrate their expertise and share knowledge $(M=3.47, S D=1.24)$.

Table 7: One sample t-test statistics of the comparison of cooperating teachers' perception rating score on knowledge, belief, and commitment

\begin{tabular}{lllllll}
\hline & \multicolumn{7}{c}{ Test Value = 3 } \\
\cline { 2 - 7 } & Mean & SD & T & df & $\begin{array}{l}\text { Sig. (2- } \\
\text { tailed) }\end{array}$ & $\begin{array}{l}\text { Mean } \\
\text { Difference }\end{array}$ \\
\hline Belief & 2.7946 & .57141 & -2.357 & 42 & .023 & -.20543 \\
Commitment & 3.2703 & .82778 & 2.142 & 42 & .038 & .27035 \\
Perceived benefit & 3.0598 & 1.17234 & .334 & 42 & .740 & .05980 \\
Knowledge & 3.4186 & .89337 & 3.073 & 42 & .004 & .41860 \\
\hline
\end{tabular}

A one sample t-test analysis was conducted to ascertain if the difference between the actual and the expected mean score was statistically different. Accordingly, the mean score on knowledge of mentoring was found to be statistically significant and above the expected mean value $(M=3.42, t=3.073, d f=42, p<0.05)$. on the other hand, though the mean score on the view of mentoring as a professional development approach for cooperating teachers was marginally above the expected mean value, the result was not statistically significant $(M=3.06, S D=1.17, t=.334, d f=42, p>0.05)$.

In terms of commitment to mentoring role, the mean score was found to be above the expected mean value and statistically significant $(M=3.27, S D=.83, t=2.142, d f=42, p<0.05)$. The result suggested that cooperating teachers were committed to their role as cooperating teachers of PGDT trainees. Nevertheless, the result on the belief component was found to be statistically below the expected mean $(M=2.80, S D=.57, t=-2.357, d f=42$, $p<0.05)$. The result is indicative of the fact that though cooperating teachers feel they themselves were committed; their influence on shaping attitude and professional disposition of mentees was limited. This might be because they believed that mentees' attitude and professional disposition was largely influenced by factors beyond the control of cooperating teachers. 
Table8 : Pearson's correlation analysis of cooperating teachers' perception rating score on knowledge, belief, commitment

\begin{tabular}{lllll}
\hline Correlations & & $\mathbf{1}$ & $\mathbf{2}$ & $\mathbf{3}$ \\
\hline 1.Knowledge & Pearson Correlation & 1 & $.697^{* *}$ & $.833^{* *}$ \\
& Sig. (2-tailed) & & .000 & .000 \\
2.Belief & Pearson Correlation & $.697^{* *}$ & 1 & $.585^{* *}$ \\
& Sig. (2-tailed) & .000 & & .000 \\
3.Commitment & Pearson Correlation & $.833^{* *}$ & $.585^{* *}$ & 1 \\
& Sig. (2-tailed) & .000 & .000 & \\
\hline
\end{tabular}

**. Correlation is significant at the 0.01 level (2-tailed).

The table above indicated that there was a positive and moderately strong positive relationship between knowledge of goals and processes of mentoring and belief of cooperating teachers in their abilities to influence student-teachers' professional disposition $(r=.697, p<0.01)$. This indicates that as the knowledge of cooperating teachers improves, so does their self-efficacy in their own ability to positively shape future professionals. The result also indicated that there was strong positive relationship between knowledge of goals and processes of mentoring and cooperating teachers' commitment to mentoring role $(r=.833, p<0.01)$. This means that improving cooperating teachers' knowledge of mentoring helps to ensure their commitment to the role. It was also found that there was a positive and moderate relationship between belief in ones' own ability to positively influence student-teachers' professional disposition and commitment to mentoring role $(r=.585, p<0.01)$. It can be seen that, though positive, the relationship between belief and commitment was not as strong as the relationship between knowledge and commitment. This might be because cooperating teachers were executing their responsibilities as effectively as stated in the practicum guideline but still were uncertain whether their efforts or the four weeks of stay of student-teachers was adequate enough to positively influence student teachers' professional disposition.

Table 9: Perceived challenges of Cooperating teachers regarding their mentoring role

\begin{tabular}{lcc}
\hline \multicolumn{1}{c}{ Items } & Mean & SD \\
\hline Lack of enough time to work with the mentee due to high teaching workload. & 3.05 & .899 \\
Poor cooperation between university lecturers and cooperating teachers to discuss & 2.95 & .899 \\
mentees' progress. & 2.93 & .856 \\
Lack of incentive for the responsibility of being a mentor. & 2.84 & .871 \\
Inappropriate time arrangement of the practicum program. & 2.79 & .940 \\
Mentees lack of adequate planning \& preparation for their responsibilities. & 2.72 & 1.16 \\
Late arrival/early departure of mentees during practicum. & 2.70 & .914 \\
Poor follow up, feedback and support system from university officials. & 2.67 & .969 \\
Inadequate attention given to the mentoring role by cooperating teachers. & 2.58 & 1.03 \\
Mentees' reluctance to interact with other teachers of the School. & 2.53 & .984 \\
\hline Inadequacy of assistance from the school administrators.
\end{tabular}

The last part of the questionnaire focused on measuring the most challenging factors affecting cooperating teachers' mentoring role. On a scale of 1 to 4 where 1 represented 'not a challenge at all and 4 representing 'A very series challenge', respondents' lack of adequate time to work with mentees due to high teaching workload $(M=3.05, S D=0.899)$, poor cooperation between university supervisors (tutors) and cooperating teachers $(M=2.95, S D=.899)$, lack of incentive package for being a mentor $(M=2.93, S D=.856)$, inappropriate time arrangement of the practicum program $(M=2.84, S D=.871)$, and mentees' lack of adequate planning and preparation for their responsibilities $(M=2.79, S D=.940)$ as the most severe challenges of their mentoring role.

\subsection{Discussion}

High-quality teacher preparation requires effective planning. Mentoring, being a core component of studentteachers teaching practice, demands a sustained interaction and dialogue among key stakeholders where university instructors, student-teachers and cooperating teachers take the lion's share. Cooperating teachers influence student-teachers' profession-related socialization, career satisfaction, perceptions of the professional role, philosophies of teaching, instructional practices, and perhaps even their decision to stay in the profession (Brouwer \& Korthagen, 2005). As a result the role cooperating teachers should be play in teacher education programs could not be over emphasized.

The purpose of this study was to investigate cooperating teachers' knowledge, belief and commitment to mentoring role with particular reference to cooperating teachers in secondary schools of Bahir Dar City. As such the findings indicated that cooperating teachers had no adequate training opportunities. The fact that mentoring requires multi-faceted skills calls for continuous professional development to be prepared by the university. 
Mentoring relationships are most effective when cooperating teachers are trained for their roles (Pitton, 2006; Wong, 2005).

Hobson (2002) argues that mentoring is so crucial to quality teacher training and therefore, all teachers in schools which participate in pre-service teacher training should be aware of the importance of mentoring and should have some ideas about how to perform such a role effectively. In this regard, the finding indicated that cooperating teachers had adequate knowledge of the goals and processes of mentoring. And this was found to be positively correlated with their belief regarding their abilities to positively impact mentees' disposition and their commitment to mentoring role. Nevertheless, the findings also indicated that the level of belief of cooperating teachers was below the expected level. These results indicated that there were other factors which the cooperating teachers believed impacted mentees' professional disposition and attitude to the profession. Moreover, inadequate planning and preparation of student-teachers during classroom teaching was identified as one of the severe challenges impacting their mentoring role. This indicates that the university, school administrations and cooperating teachers and student-teachers should have a dialogue on good experiences and limiting factors frequently.

As mentoring is an interactive learning process that occurs within a social context, effective communication and relationship skills are also needed. Learning is most effective when it is collaborative, actively involves the learner and is situated within the context of the learner (Osterman \& Kottkamp, 2004). Reflection is a critical examination of one's own practices and it is through reflection that cooperating teachers may scrutinize their own practices (Jones \& Straker, 2006) and explicate them to mentees. It is not sufficient for cooperating teachers to merely have the skills of reflection but they must be able to convey their pedagogical knowledge, and how it translates into practice, to others, namely to their mentees (Alred \& Garvey, 2000).

Expert mentoring not only allows beginning teachers to develop competence more quickly (DarlingHammond, 2003) but also lays the foundation for innovative professional practice (Evertson \& Smithey, 2001). As such, student-teachers need to have adequate reflection opportunities with the help of cooperating teachers. For this, cooperating teachers should have an understanding of the benefits of reflective teaching. In this way, mentoring could be mutually beneficial for cooperating teachers and mentees (Hall, Draper, Smith \& Bullough Jr, 2008) and lead to the betterment of education quality in secondary schools.

Mentoring needs to be viewed as a symbiotic relationship in which cooperating teachers benefit from the mentoring process. These benefits include encouraging reflections on one's own knowledge, beliefs and practices and a renewal and revitalization of practice (Murray, Mitchell \& Dobbins, 1998), thus building capacity in the profession. Nevertheless, the finding revealed that cooperating teachers do not seriously believe in the role of mentoring for their own professional development. This belief of cooperating teachers contrasts with Sandholtz and Wasserman (2001) and Landt (2004) who in their studies found that cooperating teachers evidenced an improvement in their own teaching, and they credited their work as a mentor.

The study also revealed that there was poor communication between cooperating teachers and university tutors regarding the progress of the mentee. This finding was similar with Payant and Murphy (2012) studied cooperating teachers' perceptions of their roles in guiding the student-teachers of English and their study showed that the communication between the cooperating teachers and practicum course instructors was poor.

\subsection{Conclusions}

Periodic meetings between university tutors and cooperating teachers during student teachers field experience are pivotal. Holding more short-term trainings and communicating systematically with the cooperating teachers and other supportive interactions are essential to the development of an effective mentoring process. The university needs to recognize the impact cooperating teachers have on student teachers. Without the contributions and services provided by dedicated cooperating teachers for the professional development of student teachers, the quality of the university's training program would be highly compromised.

\subsection{Recommendations}

$>$ It is important that the university value cooperating teachers' commitment and dedication to the student teachers practicum experience. It is imperative that the university recognize the challenges that cooperating teachers face and provide the necessary training and materials to ensure the highest quality student teaching experience.

$>$ The university needs to further strengthen the partnerships with school districts, and the university supervisor needs to work closely with the cooperating teachers and school administration to create settings that would enhance the student teaching field experience.

$>$ To enhance the work of cooperating teachers, the university must first look at the university tutors. Selection of university tutors who have the necessary disposition to be a collaborator and colleague is imperative. The university supervisor (tutors) must be respectful and supportive of the cooperating teacher. 
$>$ The university needs to provide training for university supervisors. This training should address expectations for cooperating teachers, ways to support student teachers and cooperating teachers, and ways to deal with difficult situations. Also, because university supervisors play an important role in guiding and supporting cooperating teachers, their workload needs to be reasonable so they can spend more time working with cooperating teachers and student teachers.

$>$ The university should also provide training for cooperating teachers. They need to have a better understanding of the expectations for them and the student teacher. The role of mentoring as an opportunity for professional development of the student teacher should be emphasized.

$>$ That university must hold regular workshops to discuss on the quality of mentorship provided to student teachers.

\section{References}

Adugna, B. (2012). Assessment of the Attitude of Prospective Teachers Enrolled in Postgraduate Diploma in Teaching: The Case of Wollega University. Science, Technology and Arts Research Journal, 1(4), 65-73.

Alred, G., \&Garvey, B. (2000). Learning o produce knowledge: the contribution to mentoring. Mentoring and Tutoring, 8, 261-272.

Anderson, D. (2007). The role of cooperating teachers' power in student teaching. Education, 28, 307-323.

Awaya, A. McEwan, H. Heyler, D. Linsky, S. Lum, D. and Wakukawa, P. 2003.Mentoring as a Journey. Teaching and Teacher Education, 19, 45-56

Boyle, P. and Boice, B., 1998. Systematic Mentoring for New Faculty Teachers and Graduate Teaching Assistants. Innovative Higher Education, 22, 157-179

Britzman, D. P. (2000). Teacher education in the confusion of our times. Journal of Teacher Education, 51, 200205. doi:10.1177/0022487100051003007

Cole, A. L. (2000). Case studies of reform in Canadian preservice teacher education.Alberta Journal of Educational Research, 40, 192-195.

Colley, H. 2003. Mentoring for Social Inclusion: A Critical Approach to Nurturing Mentor Relationships: London. Routledge Falmer

Demis,G., Haileselasie, B., \& Dawit, T. (2015). An Exploration of Student-Teachers' Views about the Practice of Postgraduate Diploma in Teaching: English Major Prospective Teachers in Bahir Dar and Haromaya Universities, Ethiopia . International Journal of Learning, Teaching and Educational Research, 13(3), 192-209.

Doty, A. D. (2006). Student teaching 101: A glimpse inside the minds of cooperating teachers. Triad, 74(2), 5051

Evertson, C. M., \& Smithey, M. W. (2000).Mentoring effects on protégés' classroom practice: An experimental field study. Journal of Educational Research, 93(5), 294-304.

Fairbanks, C. M., Freedman, D., \& Kahn, C. (2000). The role of effective mentors in learning to teach. Journal of Teacher Education, 51(2), 102-112.

Furlong, J. \& Maynard, T. (1995). Mentoring student teachers: The growth of professional knowledge. London and New York: Rout- ledge.

Federal Democratic Republic of Ethiopia, (FDRE), 1994. Education and Training Policy, first Edition AA, ST. George Printing Press.

Hall, K. M., R. Draper, R. J., Smith, L. K. \& Bullough Jr, R.V. (2008). More than a place to teach: Exploring the perceptions of the roles and responsibilities of mentor teachers'. Mentoring and Tutoring, 16(3), 328-345.

Halloway, J.H.2011. Research Link/ The Benefits of Mentoring, Educational leadership. Available online (http://www.ascd) accessed on Sep. 25/2017

Hastings, W. (2004). Emotions and the practicum: The cooperating teachers' perspective. Teachers and Teaching: Theory and practice, 10(2), 135-148.

Heirdsfield, A. M., Walker, S., Walsh, K. \& Wilss, L. (2008). Peer mentoring for first-year teacher education students: The mentors experience. Mentoring and Tutoring, 16(2), 109-124.

Hobson, A.J. (2002). Student teachers' perceptions of school-based mentoring in initial teacher training (ITT). Mentoring and Tutoring, 10(1). 5-20

Hudson, Peter B. and Usak, Muhammet and Savran-Gencer, Ayse (2009) Employing thefive-factor mentoring instrument : analysing mentoring practices for teaching primaryscience. European Journal of Teacher Education, 32(1). pp. 63-74.

Jones, M., \&Straker, K. (2006). What informs cooperating teachers' practice when working with trainees and newly qualified teachers? An investigation into cooperating teachers' professional knowledge. Journal of Education for Teaching, 32(2), 165-184.

Kothari, C. R. 2004. Research Methodology. Methods and Techniques. (2nd ed). New New Delhi: Age International $(\mathrm{P}) \mathrm{Ltd}$.

Koye, K. (2014). Attitude of Postgraduate Diploma in Teaching (PGDT) Student Teachers towards Teaching 
Profession in Ethiopian University College of Teacher Education. Middle Eastern \& African Journal of Educational Research, Issue 7, 44-77.

Koye, K. and Yonas, A. (2013). Practices and Challenges of Post-Graduate Diploma in Teaching Programme: The Case of Haramaya University, Ethiopia. An International Multidisciplinary Peer Reviewed E-Journal, 2(4), 254- 274

Kram, K.E. (1985). Mentoring at Work. Developmental Relationships in Organizational Life. Glenview, IL; Scott, Foreman and Co.

Kreitner, R., and Kinicki, A.,(2004). Organizational behavior: (6th ed.). Boston: McGraw-Hill.

Landt, S. M. (2004). Professional development of middle and secondary level educators in the role of cooperating teacher. Action in Teacher Education, 26(1) 74-84.

Malderez, A (2001) New ELT professionals, English Teaching Professional, 19, 57-58

Ministry of Education (2003). A National Curriculum Guidance for Pre-service Teacher Education Programs. AA.

Ministry of Education, (2005). Education Sector Development Program III. Program Action plan:Addis Ababa

O'Brien, E., \& Hamburg, I. (2014). Supporting sustainable strategies for SMEs through training, cooperation and mentoring. Higher education studies, 4(2), 61-69.

Osterman, K. F., \&Kottkamp, R. B. (2004). Reflective practice for educators: Professional development to improve student learning(2nd ed.). Thousand Oaks, CA: Corwin Press.

Payant, C., \& Murphy, J. (2012). Cooperating teachers' roles and responsibilities in an MATESOL practicum. TESL Canada Journal, 29(2), 1-23.

Pitton, D. E. (2006). Mentoring novice teachers: Fostering a dialogue process(2nd ed.). Thousand Oaks, CA: Corwin Press.

Samakange W (2015). Examining the role of the mentor in teacher education in Zimbabwe: Global Journal of advanced researchVol-2, Issue-2 PP. 521-533

Sandholtz, J. H., \& Wasserman, K. (2001). Student teacher and cooperating teachers: Contrasting experiences in teacher preparation programs. Action in Teacher Education, 23(3), 54-65.

Schwille, S.A. (2008). The professional practice of mentoring. American Journal of Education, 115(1), $139-167$.

Smith, A. (2007) Mentoring for experienced school principals: Professional Learning in a safe place. Mentoring and Tutoring, 15 (3), 277-291

Sweeny, B.W. and De Bolt, G.P. ,(2008). A survey of 50 States: Mandated Teacher Induction Programs. Indianapolis: kappa Delta

Sweeny, B. W. (2008). Leading the teacher induction and mentoring program(2nd ed.). Thousand Oaks, CA: Corwin Press.

Solomon, Melesse (2013). The state of student-teachers' support service rendered from cooperative teachers as school-based practitioners: The Case of Bahir Dar University, Amhara Region, Ethiopia Vol. 8(23), pp. 2212-2223, Educational Research and Reviews

Stockdale, M., and Murphy, K. (2002). The value of mentoring (http://www.med.unc.edu/wrkunits/orgs/apwims/trower_xx_tenure_sci.pdf) accessed on December 17/2017.

Turban, D. B., \& Lee, F. K. (2007). The role of personality in mentoring relationships. In B.Ragins \& K. Kram (Eds.), The handbook of mentoring at work: Theory, research, and practice (pp. 21-50). Los Angeles, CA: Sage.

Wang, J., \& Odell, S. J. (2002). Mentored learning to teach according to standards-based reform: A critical review. Review of Educational Research, 72(3), 481-546.

Wong, H. K. (2005). New teacher induction: The foundation for comprehensive, coherent, and sustained professional development In H. Portner (Ed.), Teacher mentoring and induction: The state of the art and beyond (pp. 41-58). Thousand Oaks, CA: Corwin Press.

Zemek, M. D. (2008). The selection and preparation of cooperating teachers in music education. Journal of Music Teacher Education, 17(2), 7-18. 